\title{
IDENTIFICACIÓN DE VIRUS EN EL CULTIVO DE CAMOTE (Ipomoea batatas L.) EN COSTA RICA1
}

\author{
Rodrigo Valverde ${ }^{2}$, Marco A. Moreira ${ }^{3}$
}

\begin{abstract}
RESUMEN
Identificación de virus en el cultivo de camote (Ipomoea batatas L.) en Costa Rica. En el período entre febrero y mayo del 2002, se realizó un reconocimiento de los virus del cultivo de camote (Ipomoea batatas L.), en cinco plantaciones comerciales ubicadas en las principales regiones productoras de este cultivo en Costa Rica. Previo al muestreo, en cada plantación se evaluó la incidencia de plantas con síntomas de enfermedades virales. Para la identificación de los virus, se recolectaron secciones apicales de tallo de plantas de camote con síntomas las cuales se injertaron sobre las plantas indicadoras de virus, de la especia Ipomoea setosa para inocularlas. Las muestras foliares de plantas inoculadas fueron analizadas serológicamente para el virus del moteado plumoso del camote (SPFMV) y el virus del mosaico del pepino (CMV); con la reacción en cadena de polimerasa de transcripción reversa (RT-PCR) para el virus del enanismo clorótico del camote (SPCSV ) y por hibridación molecular para el virus del enrollamiento de la hoja del camote (SPLCV). Las plantaciones ubicadas en el Cacao y el Coyol de Alajuela, y San Pedro de Santa Bárbara, presentaron las mayores incidencias de plantas con síntomas virales; a saber: 30, 90 y $90 \%$ respectivamente. El SPFMV, transmitido por los áfidos fue el virus más común. Otros virus detectados fueron el SPCSV y el SPLCV. El CMV, no se encontró en ninguna de las muestras analizadas.
\end{abstract}

\begin{abstract}
Identification of sweet potato (Ipomoea batatas $\mathbf{L}$.) viruses in Costa Rica. A survey for sweet potato (Ipomoea batatas $L$.) viruses was conducted in five commercial fields in Costa Rica from February to May 2002. High percentage of plants showing virus-like symptoms were observed in three of the five commercial fields. Graft-inoculations of fieldcollected samples to the virus indicator plant Ipomoea setosa were conducted. Foliar samples from inoculated plants were tested serologically for Sweet potato feathery mottle virus (SPFMV) and Cucumber mosaic virus (CMV), by reverse transcription polymerase chain reaction (RT-PCR) for Sweet potato chlorotic stunt virus (SPCSV), and by molecular hybridization for Sweet potato leaf curl virus (SPLCV). The aphid-transmitted SPFMV was the most common virus detected. Other viruses detected included SPCSV and SPLCV. CMV was not detected in any of the samples tested. Mixed infections of SPFMV and SPCSV were detected in the 3 commercial fields with a high percentage of plants showing virus-like symptoms. The identity of SPCSV was confirmed by whitefly (Bemisia tabaci) transmissions and RNA analysis of selected RT-PCR positive samples.
\end{abstract}

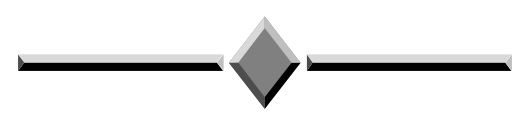

\section{INTRODUCCIÓN}

El camote (Ipomoea batatas Lam) es un cultivo ampliamente producido en las regiones tropicales y templadas calientes. Este es uno de los cultivos alimenticios más importantes, versátiles y subexplotados en el mundo. Con una producción anual de 122 millones de tone- ladas métricas, el camote se ubica en el cuarto lugar en el mundo en vías de desarrollo, después del arroz, el trigo y el maíz (FAO 1998). Las enfermedades del camote pueden ser causadas por hongos, bacterias, fitoplasmas o virus y la severidad varía desde ausencia de síntomas hasta la muerte de las plantas infectadas, dependiendo del patógeno y de las condiciones ambientales (Clark et

\footnotetext{
1 Recibido para publicación el 2 de octubre del 2003.

2 Departamento de Fitopatología y Fisiología Vegetal. Universidad Estatal de Louisiana. Estados Unidos de América. Correo electrónico: rvalverde@1suvm.sncc.lsu.edu

3 Programa de Hortalizas, Estación Experimental Fabio Baudrit, Universidad de Costa Rica. Correo electrónico: mmoreira@cariari.ucr.ac.cr
} 
al. 2002). Sin embargo, por ser un cultivo que se propaga en forma vegetativa, es muy propenso a acumular virus. Los virus son uno de los factores que causan las mayores reducciones en rendimiento y calidad y se ha sugerido que estos pueden contribuir al deterioro progresivo de los cultivares de camote (Moyer and Salazar 1989, FAO 1998). Los virus del camote son difíciles de transmitir mecánicamente, aparecen en infecciones combinadas y su amplia gama de hospederos está frecuentemente restringida a la familia Convulvulaceae.

Los áfidos y las moscas blancas se mencionan como los insectos vectores más importantes de los virus del camote (Moyer y Salazar 1989). El virus del moteado plumoso del camote (SPFMV) se encuentra prácticamente en todo lugar donde se cultive el camote. Este virus es transmitido por áfidos y pertenece a la familia Potyviridae, una de las familias más grandes de los virus vegetales (Moyer y Salazar 1989, Abad y Moyer 1992, Kreuze et al. 2000). Durante los últimos 10 años, los virus transmitidos por la mosca blanca se han convertido en el mayor grupo de patógenos en muchos cultivos, incluyendo el camote en los trópicos y subtrópi$\cos$ en el mundo, especialmente en el hemisferio occidental (Brown y Bird 1992, Polston y Anderson 1997). El virus de enanismo clorótico del camote (SPCSV) es transmitido por la mosca blanca del género Crinivirus. Este virus, en infecciones combinadas con el SPFMV causan una severa enfermedad en el camote llamada enfermedad viral del camote (SPVD) (Winter et al. 1992, Gibson et al. 1998, Alicai et al. 1999). Esta se considera la enfermedad más grave para la producción de camote en Africa (Alicai et al. 1999). Así mismo, se ha descrito como un problema creciente en diferentes países y su diseminación podría estar asociada con la expansión geográfica de la mosca blanca. El otro virus transmitido por la mosca blanca, el virus de enrollamiento de la hoja del camote (SPLCV), pertenece al género Begomovirus y a la familia Geminiviridae, existe en Estados Unidos de América (Lotrakul et al. 1998, Lotrakul y Valverde 1999). En un estudio con introducciones de plantas de varios países, se encontró que el SPLCV y virus relacionados están en China, Brasil, México, Perú y Puerto Rico (Lotrakul et al. 2002).

Para definir estrategias más eficientes de protección del cultivo, es necesario un mejor conocimiento de los virus y las cepas involucradas, su distribución geográfica y los potenciales hospederos y reservorios de virus y vectores. En los últimos años, los productores en Costa Rica han observado una reducción progresiva del rendimiento en el cultivo de camote; es muy probable que esta merma, sea causada por una acumulación de virus. El objetivo principal de esta investigación fue determinar la identidad de algunos de los principales virus que afectan al cultivo de camote en Costa Rica.

\section{MATERIALES Y MÉTODOS}

Durante los meses de febrero y marzo del 2002, se colectaron muestras de tallos de plantas de camote con síntomas de virus, en fincas comerciales en varias localidades tradicionalmente productoras de este cultivo en Costa Rica. La ubicación geográfica y el número de muestras obtenidas en cada localidad, se detalla en el Cuadro 1. Durante la recolección de las muestras en cada sitio, se realizaron inspecciones visuales y se estimó el porcentaje de plantas infectadas con virus en el área cultivada.

Cuadro 1. Ubicación geográfica y número de muestras colectadas en las localidades muestreadas para la identificación de los virus en el cultivo de camote. Costa Rica. 2002.

\begin{tabular}{|c|c|c|c|c|}
\hline Localidad & $\begin{array}{c}\text { Latitud } \\
\text { Norte }\end{array}$ & $\begin{array}{l}\text { Longitud } \\
\text { Oeste }\end{array}$ & $\begin{array}{l}\text { Elevación } \\
\text { (m.s.n.m.) }\end{array}$ & $\begin{array}{c}\text { \# de } \\
\text { muestras }\end{array}$ \\
\hline \multicolumn{5}{|l|}{ Alajuela } \\
\hline El Cacao & $10^{\circ} 01^{\prime}$ & $84^{\circ} 16^{\prime}$ & 846 & 6 \\
\hline El Coyol & $10^{\circ} 00^{\prime}$ & $84^{\circ} 14^{\prime}$ & 842 & 7 \\
\hline Barrio San José & $10^{\circ} 01^{\prime}$ & $84^{\circ} 06^{\prime}$ & 840 & 6 \\
\hline \multicolumn{5}{|c|}{ Heredia } \\
\hline $\begin{array}{l}\text { San Pedro, } \\
\text { Santa Bárbara }\end{array}$ & $10^{\circ} 02^{\prime}$ & $84^{\circ} 10^{\prime}$ & 1146 & 13 \\
\hline \multicolumn{5}{|l|}{ Cartago } \\
\hline Turrialba & $9^{\circ} 52^{\prime}$ & $83^{\circ} 38^{\prime}$ & 590 & 5 \\
\hline \multicolumn{5}{|l|}{ Limón } \\
\hline La Rita, Pococí & $10^{\circ} 16^{\prime}$ & $83^{\circ} 47^{\prime}$ & 111 & 5 \\
\hline
\end{tabular}

El uso de I. Setosa, que es considerada como un huésped universal para virus del camote, fue necesario por la dificultad para detectar los virus directamente en la planta de camote debido a su alto contenido de látex. Las plantas injertadas se mantuvieron en un invernadero en la Estación Experimental Fabio Baudrit Moreno $($ EEFBM) y los síntomas fueron evaluados y registrados 30 días después. Posteriormente se procedió a recolectar las muestras de hojas para las pruebas de virus. Todas las muestras fueron probadas contra el antisuero de la cepa común del SPFMV y el CMV usando el método de prueba de la membrana inmuno-ligada (PMIA) desarrollado por Abad y Moyer (1999). Las muestras de hojas $(0,2 \mathrm{~g})$ se extrajeron en Tris HCL buffer, $\mathrm{pH}$ 7,5 y se marcaron sobre membranas de nitrocelulosa. Las reacciones positivas y negativas se determinaron utilizando una reacción colorimétrica. El SPLCV se detectó con hibridación molecular usando un segmento de ácido desoxiribonucleico (ADN) de 947 pares de bases del genoma del SPLCV y un sistema de etiquetado no radioactivo ECL kif (Amersham, Arlington Hills, IL), descrito por Lotrakul y Valverde (1999) y Valverde et al. (1994). El 
ADN total de las 42 plantas de I. setosa inoculadas mediante injerto se extrajo usando el reactivo DNAzol ( $\mathrm{Li}$ fe Technologies Inc. Grand Island, NY).

Para detectar el SPCSV, se usó la reacción en cadena de la polimerasa de transcripción reversa (RTPCR), siguiendo el procedimiento de Alicai et al. (1999). El ARN total para la prueba fue extraído de 0,1 $\mathrm{g}$ de tejido foliar de I. setosa utilizando el reactivo TRIzol (Life Technologies Inc. Grand Island, NY). Los marcadores moleculares ("primers") usados amplificaron el fragmento de gene homólogo de la proteína de choque calórico 70 (HSP70) del SPCSV. Los marcadores moleculares ("primers") HSP70A (5'-gcagcagaaggctcgtttat-3') y HSP70B (5'-atcggcgtatgttggtggta$\left.3^{\prime}\right)$ fueron posicionados en regiones conservadas dentro del género Crinivirus y amplificaron un fragmento en alrededor de 446 pares de bases.

Se realizaron extracciones de ARN y transmisiones de mosca blanca (Bemisia tabaci) para confirmar la identidad del SPCSV. Para las transmisiones de mosca blanca, se colocaron las moscas blancas en jaulas con plantas de Ipomoea setosa sospechosas de estar infectadas con el SPCSV. Se usaron períodos de adquisición y transmisión de dos días. Para las pruebas de hospedero se usaron plántulas sanas de Ipomoea nil cv. Scarlett O'Hara (un hospedero de diagnóstico para el SPCSV). Se utilizaron grupos de aproximadamente 50 moscas para los cuatro experimentos. Las plantas se mantuvieron en una casa de malla y los síntomas se evaluaron 30 días después. La extracción y análisis de los ARN se realizó de acuerdo al método descrito por Valverde et al. (1990) y Valverde et al. (1994), usando tejido foliar de I. setosa.

\section{RESULTADOS}

La mayoría de las plantas que mostraban síntomas de virus en El Cacao, El Coyol y San Pedro, presentaron síntomas típicos de la enfermedad viral (SPVD). Los síntomas consistieron en enanismo de la planta, clorósis, tonalidades purpurinas y malformación de hojas (Figura 1).

Los estimados de las posibles infecciones virales en estos campos fueron más altos que los de los lotes del Barrio San José, Turrialba y La Rita (Cuadro 2).

Todas las 42 plantas de I. setosa injertadas con las muestras recolectadas en el campo mostraron síntomas que incluyeron clorosis, mosaico, moteado y deformación foliar (Figura 2).

Los resultados de las pruebas de membrana inmuno-ligada (Figura 3), RT-PCR e hibridación molecular

Cuadro 2. Porcentaje de plantas de camote (Ipomoea batatas L.) con síntomas de virus en los lotes comerciales muestreados. Costa Rica. 2002.

\begin{tabular}{lc}
\hline \multicolumn{1}{c}{ Localidad } & $\begin{array}{c}\text { \% plantas } \\
\text { con síntomas }\end{array}$ \\
\hline El Cacao de Alajuela & 30 \\
El Coyol de Alajuela & 90 \\
Barrio San José de Alajuela & 10 \\
San Pedro de Santa Bárbara de Heredia & 90 \\
Turrialba & 1 \\
La Rita de Pococí & 1 \\
\hline
\end{tabular}

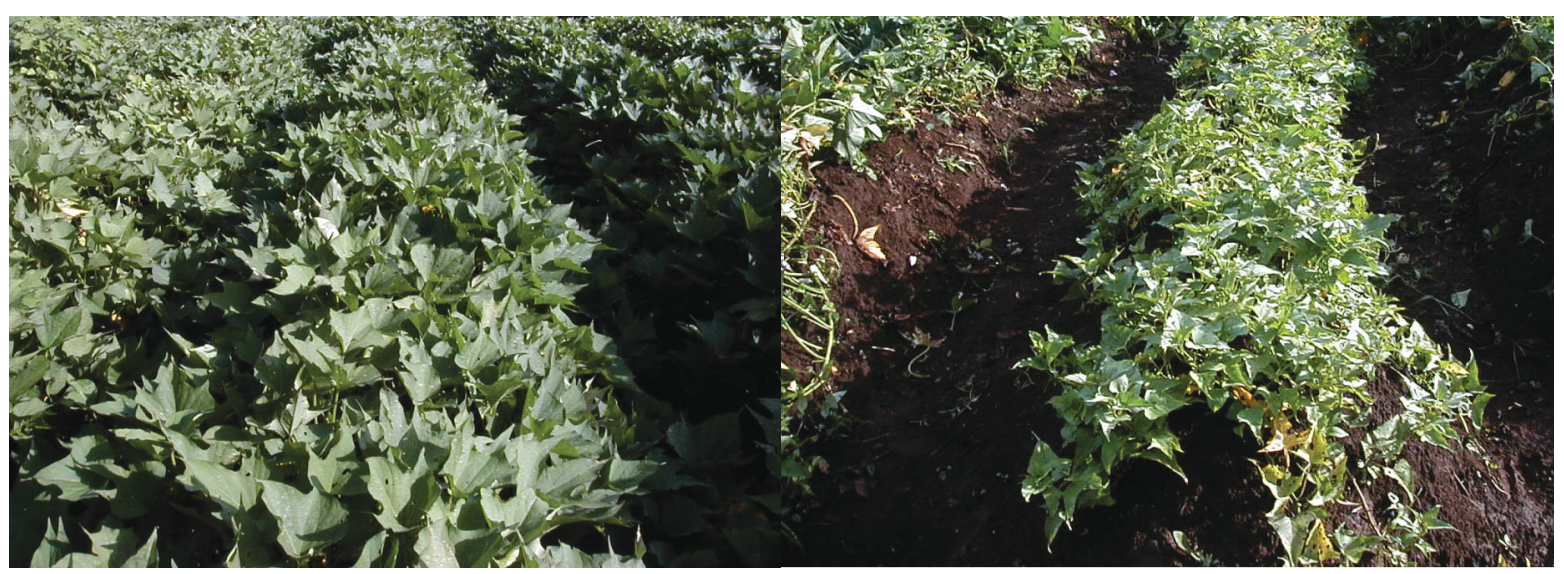

Figura 1. A la izquierda, plantas de un lote del cv. CLN-948-6 (“exportación”), 90 días después de la siembra, aparentemente sanas y a la derecha plantas del mismo cultivar y de la misma edad, infectadas con la enfermedad viral del camote (SPVD). Costa Rica. 2002. 

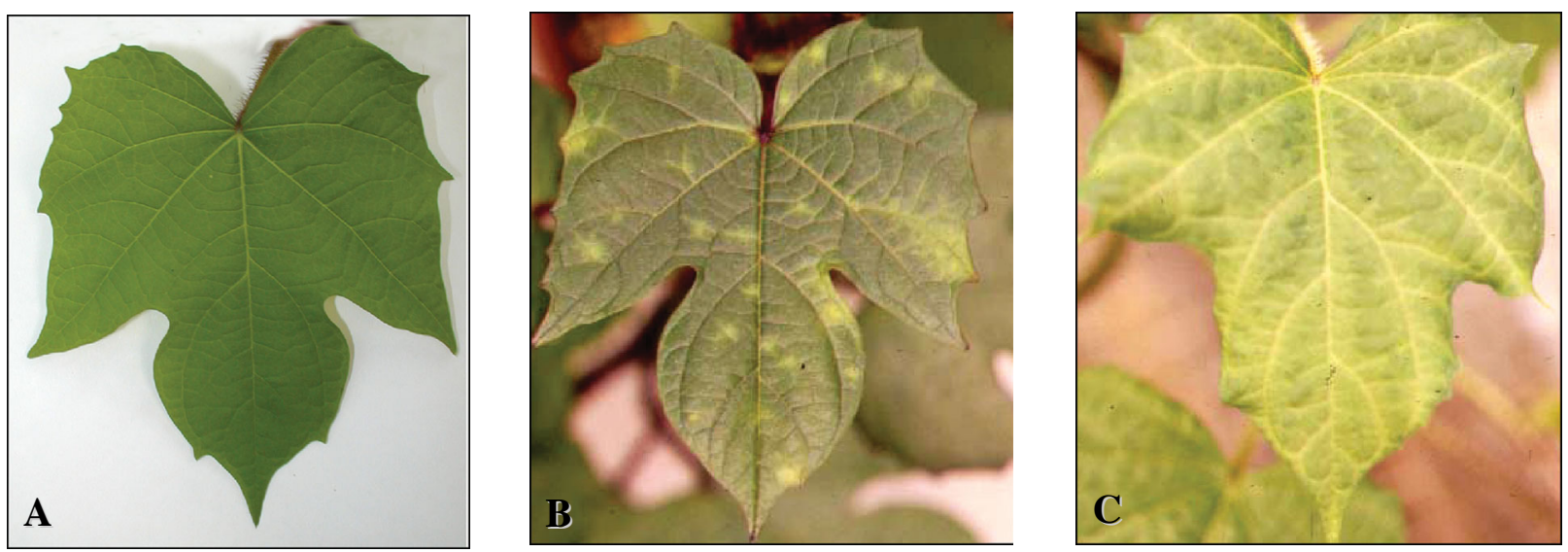

Figura 2. Apariencia de una hoja de una planta sana de Ipomoea setosa a) y síntomas observados en plantas seleccionadas de Ipomoea setosa después de la inoculación mediante injerto b) y c). Costa Rica. 2002.

indicaron que las infecciones con el SPFMV fueron las más frecuentes, seguidas por las del SPCSV y el SPLCV (Cuadro 3).

El virus del mosaico del pepino (CMV) no se encontró en ninguna de las muestras. Se detectaron infecciones combinadas del virus del moteado plumoso (SPFMV) y el virus del enanismo clorótico (SPCSV) en las muestras de los lotes que mostraron síntomas de la enfermedad viral del camote (SPVD). La identidad del SPCSV fue confirmada con transmisiones exitosas de la mosca blanca y con el análisis de ARN de muestras seleccionadas. Las plantas de I. nil utilizadas como plantas de prueba en estos ensayos, mostraron los síntomas típicos de clorosis y deformación de hojas como los causados por el SPCSV (Sim et al. 2000) (Figura 3). Los resultados (de las muestras seleccionadas) de los análisis de gel electroforesis de productos RCP y ARN se presentan en la Figura 4. Solo en dos muestras positivas se detectó el SPLCV con la hi- bridación molecular, una muestra proveniente de El Coyol y otra de La Rita.

\section{DISCUSIÓN}

Para definir una estrategia de manejo de las enfermedades virales en camote, es fundamental generar información precisa de cuales virus están involucrados y desarrollar los medios para detectar su presencia. Cuando esto se haya logrado, será posible desarrollar procedimientos de control de calidad en los programas la producción de semilla y luego iniciar un proceso racional para el control de enfermedades.

La merma progresiva en el rendimiento y la calidad en los cultivares de camote, después de su liberación, se ha reconocido como un problema mundial (Brown y

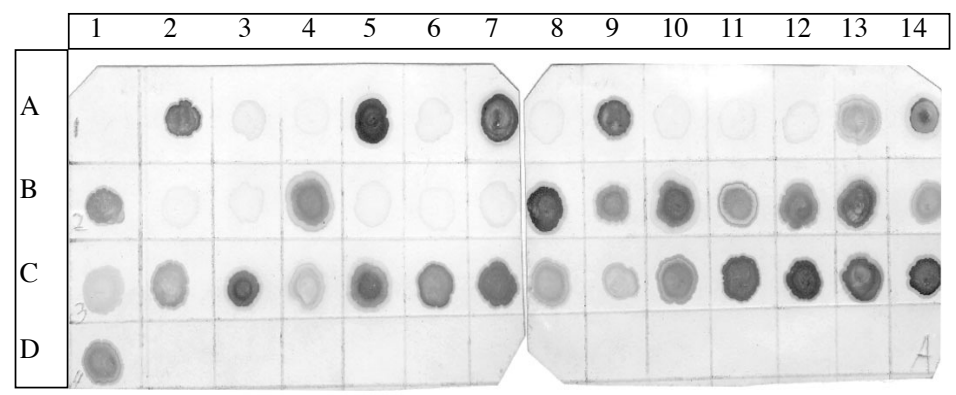

Figura 3. Prueba de la membrana inmuno-ligada usando antisuero específico al virus del moteado plumoso del camote. Costa Rica. 2002.1/

1/ Las muestras (A,B y D 1-14) marcadas en la membrana fueron extractos de savia de las plantas de I. setosa inoculadas mediante injerto con las 42 muestras recolectadas en el campo. La muestra D1 es el testigo positivo del SPFMV. 
Cuadro 3. Frecuencia de virus detectados en muestras de I. setosa injertada con secciones apicales de tallos colectados en los lotes comerciales. Costa Rica . 2002.

\begin{tabular}{lcccccc}
\hline Localidad & SPFMV & SPCSV & SPCLV & $\begin{array}{c}\text { SPFMV+ } \\
\text { SPCSV }\end{array}$ & $\begin{array}{c}\text { SPFMV+ } \\
\text { SPCLV }\end{array}$ & $\begin{array}{c}\text { Total de } \\
\text { muestras }\end{array}$ \\
\hline $\begin{array}{l}\text { Alajuela } \\
\quad \text { El Cacao }\end{array}$ & 6 & 6 & 0 & 6 & 0 & 6 \\
$\quad \begin{array}{l}\text { El Coyol } \\
\quad \text { arrio San José }\end{array}$ & 7 & 5 & 1 & 5 & 1 & 7 \\
$\quad \begin{array}{l}\text { Heredia } \\
\quad \text { San Pedro, Santa Bárbara }\end{array}$ & 8 & 0 & 0 & 0 & 0 & 6 \\
$\quad \begin{array}{l}\text { Cartago } \\
\quad \text { Turrialba }\end{array}$ & & 6 & 0 & 6 & 0 & 13 \\
$\quad$ Limón \\
$\quad$ La Rita, Pococí & 3 & 1 & 0 & 1 & 0 & 5 \\
$\quad$ Total & 3 & 0 & 1 & 0 & 1 & 5 \\
\hline & $\mathbf{3 0}$ & $\mathbf{1 8}$ & $\mathbf{2}$ & $\mathbf{1 8}$ & $\mathbf{2}$ & $\mathbf{4 2}$ \\
\hline
\end{tabular}

Bird 1992). Los virus del camote no solo afectan el rendimiento, sino que también causan un impacto negativo en la preservación e intercambio de germoplasma. Antes de la implementación de los programas de producción de material de propagación de camote libre de virus en Japón, China, Estados Unidos de América y otros países, era común que todas las plantas estuvieran infectadas con el CMV o cualquier otro virus (Clark et al. 2002). El potyvirus SPFMV es el más común y el más ampliamente distribuido y se le encuentra frecuentemente en infecciones combinadas con otros virus (Moyer y Salazar 1989). Otros potyvirus se encuentran con menos frecuencia y en algunos casos están restringidos geográficamente. Sin embargo, el aislamiento e
A

PM Inf. Inf. San.

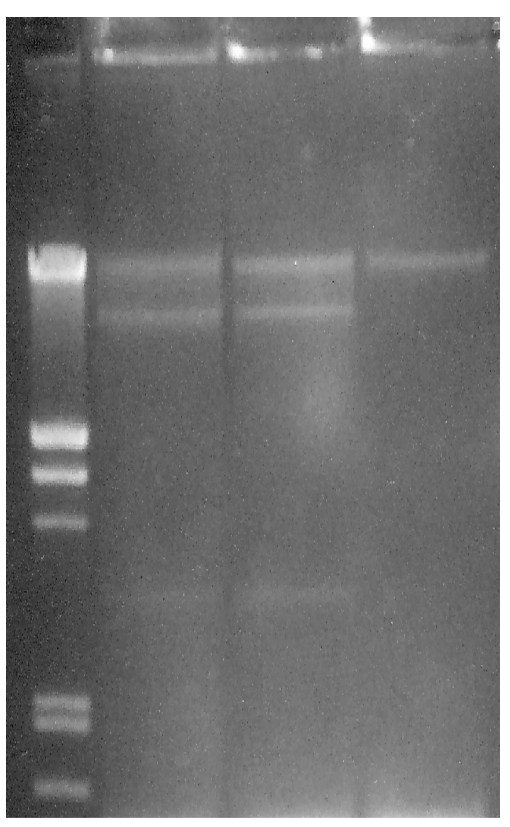

B

PM Inf. Inf. Inf. San.

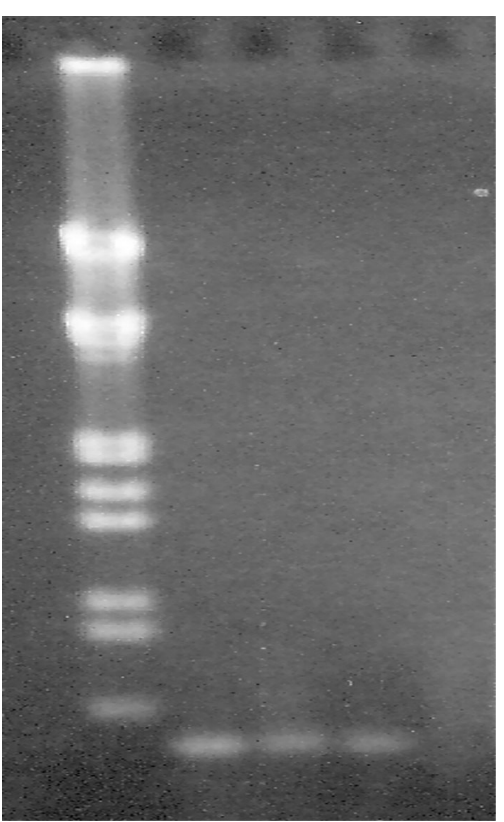

Fig. 4. Electroforesis de gel de agarosa $(1,2 \%)$ de: ARN (A) extraído de tres plantas de Ipomoea nil, dos infectadas (Inf.) con el virus de enanismo clorótico del camote (SPCSV) y una sana (San.) y ADN (B) amplificado por la RT-PCR de tres plantas de I. nil infectadas con el SPCSV y una sana. ${ }^{1 /}$

1/ El marcador de peso molecular (PM) es î ADN, cortado con Eco RI y Hind III. 
identificación de estos otros virus ha sido impedido por la presencia universal del SPFMV. El grupo de los potyvirus tiene una importancia muy particular, ya que inducen a menudo un sinergismo negativo en infecciones combinadas con otros virus, por ejemplo los severos efectos producidos por la coinfección del SPFMV y el SPCSV en el cultivo de camote en África (Alicai et al. 1999, Gibson et al. 1998, Winter et al.). En el presente estudio, la mayoría de las muestras recolectadas estaban infectadas con el SPFMV. No obstante, sólo 30 de las 42 muestras reaccionaron al antisuero de este virus. Las 12 muestras negativas eran de plantas de I. setosa que mostraron síntomas de virus, lo que sugiere que otros virus no identificados estaban presentes en estos lotes. Una inspección visual de tres lotes en El Coyol, El Cacao y San Pedro reveló que un alto porcentaje de las plantas mostraban síntomas como de virus. Este resultado no fue una sorpresa ya que la inspección a la finca en El Coyol, la cual era la fuente de material de propagación para la mayoría de las fincas de la región, también presentaba un alto porcentaje de las plantas con los mismos síntomas. Uno de los logros más importantes de esta investigación, fue la determinación de altas tasas de infección del SPFMV y del SPCSV y especialmente de infecciones combinadas de estos virus; que causan la enfermedad viral del camote. Esta enfermedad que se ha venido agravando en los últimos años, reduce drásticamente y en forma progresiva el rendimiento del cultivo.

La presencia de la enfermedad viral, el aumento en las poblaciones y la aparición de nuevos biotipos de las moscas blancas; así como la carencia de un programa de producción de semilla certificada, constituyen una seria amenaza para el cultivo de camote en nuestro país.

Con base en la literatura disponible o accesada, este es el primer informe de la presencia de tres virus del camote en Costa Rica el SPFMV, el SPLCV y el SPCSV. No obstante, la severidad de los síntomas inducidos por las inoculaciones de injerto con las muestras de campo sobre I. setosa, sugiere que otros virus podrían estar presentes. Las investigaciones futuras deberán orientarse, no sólo al desarrollo de un programa de certificación de semilla, sino también al aislamiento, identificación, caracterización y a generar los métodos de detección de cada uno de los virus no identificados.

\section{AGRADECIMIENTO}

Los autores desean agradecer la colaboración del señor Miguel Castro Rojas, miembro del Programa de Hortalizas de la Estación Experimental Agrícola Fabio Baudrit Moreno de la Universidad de Costa Rica; durante la realización de este trabajo.

\section{LITERATURA CITADA}

ABAD, J. A.; MOYER, J. W. 1992. Detection and distribution of sweet potato feathery mottle virus in sweet potato by in vitro-transcribed RNA probes (riboprobes), membrane immunobinding assay, and direct blotting. Phytopathology 82: 300-305.

ALICAI, T.; FENBY, N.S.; GIBSON, R.W.; ADIPALA, E.; VETTEN, H.J.;FOSTER, G.D; SEAL, S.E. 1999. Occurrence of two serotypes of sweet potato chlorotic stunt virus in East Africa and their associated differences in coat protein and HSP70 homologue gene sequences. Plant Pathol. 48: 718-726.

BROWN, J. K. ; BIRD, J. 1992. Whitefly-transmitted geminiviruses and associated disorders in the Americas and the Caribbean Basin. Plant Dis. 76:220-225.

CLARK, C. A.; VALVERDE, R. A.; FUENTES, S.; SALAZAR, L. F.;MOYER, J. W. 2002. Research for improved management of sweet potato pests and diseases: cultivar decline. Acta Horticulturae 583:103-110.

F.A.O. (Food and Agriculture Organization). 1998. FAO Production Yearbook for 1996, No. 50. Rome, Italy. 50: 140-146.

GIBSON, R. W.; MPEMBE, I.; ALICAI, T.; CAREY, E. E.; MWANGA, R. O. M.; SEAL, S. E.Y VETTEN, H. J. 1998. Symptoms, aetiology and serological analysis of sweet potato virus disease in Uganda. Plant Pathol. 47:95-102.

KREUZE, J. F.; ; KARYEIJEA, R. F.; GIBSON, R. W.; VALKONEN, J. P. T. 2000. Comparison of coat protein gene sequences show that East African isolates of Sweet potato feathery mottle virus form a genetically distinct group. Arch. Virol. 145:567-574.

LOTRAKUL, P.; VALVERDE, R. A.; CLARK, C. A., SIM, J.; DE LA TORRE, R. 1998. Detection of a geminivirus infecting sweet potato in the United States. Plant Dis. 82: 1253-1257.

LOTRAKUL, P.; VALVERDE, R.A. 1999. Cloning of a DNA-A-like genomic component of sweet potato leaf curl virus: nucleotide sequence and phylogenetic relationships. Molecular Plant Pathology On-Line publication/1999/0206lotrakul.

LOTRAKUL, P.; VALVERDE, R.A.; CLARK, C.A.; HURTT, S.; HOY, M.W. 2002. Sweet potato leaf curl virus and related geminiviruses in sweet potato. Acta Horticulturae 583:135-141.

MOYER, J. W.; SALAZAR, L. F. 1989. Viruses and virus like diseases of sweet potato. Plant Dis. 73: 451-455.

POLSTON, J.E.; ANDERSON, P.K. 1997. The emergence of whitefly-transmitted geminiviruses in tomato in the Western Hemisphere. Plant Dis. 81:1358-1369. 
SIM, J.; VALVERDE, R. A; CLARK, C. A. 2000. Whitefly transmission of Sweet potato chlorotic stunt virus. Plant Dis. $84: 1250$.

VALVERDE, R. A.; NAMETH, S. T.; JORDAN, R. L. 1990. Analysis of double-stranded RNA for plant virus diagnosis. Plant Dis. 74:255-258.
VALVERDE, R. A.; ARANCIBIA, R. A.; CAN, F. 1994. Nonradioactive probes by direct labelling of ssRNA from dsRNA. BioTechniques 17:70-72.

WINTER, S.; PURAC, A.; LEGGETT, F.; FRISON, E.A.; ROSSEL, H.W.; HAMILTON, R.I. 1992. Partial characterization and molecular cloning of a closterovirus from sweet potato infected with the sweet potato virus disease complex from Nigeria. Phytopathology 82:869-875. 